\title{
Determinants of Innovative Teaching among the Indonesian Lecturers
}

Original article

DOI: $10.31992 / 0869-3617-2021-30-5-65-74$

Mohamad Arief Rafsanjani - Master of Economics Education, ORCID:0000-0002-0981-8031, Lecturer of the Department of Economics Education, Faculty of Economics, mohamadrafsanjani@unesa.ac.id Eka Hendi Andriansyah - Master of Economics Education, ORCID: 0000-0002-9401-2357, Lecturer of the Department of Economics Education, Faculty of Economics, ekaandriansyah@unesa.ac.id Universitas Negeri Surabaya; Surabaya Address: Jl. Ketintang Surabaya, Indonesia 60231

Andri Eko Prabowo - Master of Economics Education, ORCID: 0000-0002-6074-5616, Lecturer of Department of Accounting Education, aep@edu.uir.ac.id

Universitas Islam Riau

Address: Jl. Kaharuddin Nasution 113 Pekanbaru, Indonesia 28284

Nujmatul Laily - Master of Accounting, ORCID: 0000-0003-2156-692X, Lecturer of Department of Accounting, Faculty of Economics, nujmatul.laily.fe@um.ac.id

Universitas Negeri Malang

Address: Jl. Semarang No 5 Malang, Indonesia 65145

Abstract. Innovation is the main source to remain competitive in today's environment. As well as other employees, the lecturer is also required to do innovative teaching. But, encouraging lecturers' willingness to do innovative teaching is challenging due to the dual roles as teachers and researchers. This study explores the predictor of innovative teaching by applying the job-demands resources model as a theoretical anchor. This research used the online questionnaire to collect the data from 233 samples taken randomly from nineteen universities in Indonesia. This study uses structural equation modeling (SEM) to examine the research model. The result indicated that teacher-researcher role conflict negatively predicted the innovative teaching of the lecturer. Besides, occupational well-being plays a mediating variable to explain the influence of teacher-researcher role conflict on innovative teaching. This study provides critical insight into the related stakeholders, such as the universities and related ministry, regarding the negative predictor of innovative teaching. They should discover approaches to reduce the negative effect of teacher-researcher conflict on the innovation behavior of lecturer teaching activity. The universities and related ministries have to ease the issue regarding job role conflict.

Keywords: teacher-researcher role conflict, occupational well-being, innovative teaching, job demands-resources model

Cite as: Rafsanjani, M.A., Andriansyah, E.H., Prabowo, A.E., Laily, N. (2021). Determinants of Innovative Teaching among the Indonesian Lecturers. Vysshee obrazovanie $v$ Rossii $=$ Higher Education in Russia. Vol. 30, no. 5, pp. 65-74, doi: 10.31992/0869-3617-2021-30-5-65-74 (In Russ., abstract in Eng.). 


\section{Introduction}

The rise of science and technology encourages the lecturer to adapt to the current condition and improve his/her teaching skills [1]. The essential teaching skill for a higher education lecturer is innovative teaching [2]. Innovative teaching is crucial to the teacher and is a major concern in several studies across various disciplines. Besides, current technology developments are changing the learning process; thus, the old teaching methods may no longer be effective [3]. Innovative teaching implies the teacher's willingness to seek out different strategies, methods, approaches, and evaluation criteria in teaching practice [4].

Some studies agree and recognize that innovative teaching is crucial to prepare creative future professionals [4], keep students' attention and encourage class engagement [2]. But, encouraging lecturers' willingness to do innovative teaching is challenging in higher education due to the high demands of research activities [5]. Being a higher education teacher means being prepared to perform two roles as a teacher and researcher simultaneously. Teaching and research are unseparated and reciprocal activities to keep pace with the current science development [6], but teaching and research are different activities. Teaching refers to the student learning activity, and research is a creative activity to increase human knowledge, such as building, developing, and examining theories [7]. So it is unavoidable for lecturers to run into conflict in the roles. The role conflicts generate a sense of stress, dissatisfaction, and uncertainty.

Moreover, conducting teaching and research simultaneously leads the lecturers to an excessive workload. The excessive workload experienced by lecturers due to dual role demands, as a teacher and researcher, ultimately leads them to teacher-researcher role conflict (TRC). TRC is a concept where a teacher or lecturer feels those teaching activities are not fit and disturb the research activities [2]. Some works recognize that lecturers feel burdened working as both teacher and researcher due to drain of time and energy either physically or psychologically [7-8], and hard to conduct well in both roles [7].
In the job demands-resources model (JDR model), job demands are related to "those physical, social, or organizational aspects of the job that require sustained physical or mental health and are therefore associated with certain physiological and psychological cost" [9]. This study using the JDR model as a theoretical basis due to the cross-cultural validity, flexibility, can be adapted to the different fields of science [10]. Hence, it is appropriate to guide our study to examine the relationship between TRC and innovative teaching and the variables that mediate the relationship between the two, occupational well-being.

Previous studies had some limitations in applying the JDR model. First, they mostly examined partial relationships (direct relationships) in a study, not complex models. Second, the JDR model is rarely used in the context of higher education, except three works $[7 ; 11 ; 12]$. The first one ignores the mediated relationship in the JDR model, and the last two only see it as variable antecedents and consequences. The present study tries to bridge the gap by applying the JDR model in examining the relationship between TRC and innovative teaching by using occupational well-being as a mediating variable in a single study.

\section{Literature review Job demands-resources model}

There are several approaches in research related to stress, such as the job demands control model (DCM), the transactional model of stress and coping, the effort-reward imbalance model (ERI), the job characteristics model (JCM), and the job demands-resources model (JDR) [13]. The latest one, the JDR model, is gaining high popularity among researchers in the past decade due to the cross-cultural validity and flexibility [10].

In the JDR model [14], there is an assumption that each job may have its specific risks related to work stress. The risks are divided into two categories, job demands and job resources. Job demands refer to physical, social, or organizational aspects of the job associated with certain physiological and psychological costs. Job demands will trigger 
job stress if the workers need to set great effort to meet the expectations [2]. Job resources indicate to "those physical, psychological, social, or organizational aspects of the job that are functional in achieving work goals, reduce job demands and the associated physiological and psychological costs, or stimulate personal growth, learning, and development" [14]. So, job resources are utilized to minimize job demands as well as crucial for their advantages.

Based on the JDR model, there are two diverse psychological processes [14]. First, the health impairment process, where excessive job demands drain employees' mental and physic health resulting in a health problem. Second, motivational in nature, where job resources are positively related to work performance. These processes ultimately predict organizational outcomes [13]. Therefore, job resources lessen the effect of job demands and have the motivational potential for employees to give high performance.

\section{Teacher-researcher role conflict as the predictor}

Being a teacher in higher education or a lecturer means being ready to conduct the dual role professions as a teacher and researcher. On the one hand, the dual roles are the demands of the lecturer profession. It gives a great benefit to teaching and keeps pace with science development [15]. On the other hand, the dual roles lead to excessive workload due to lack of time and energy [7]. The previous studies show that lecturers feel burdened, working as both teacher and researcher due to drain of time and energy either physically or psychologically [7-8], and hard to conduct well in both roles [7].

Some literature indicates it is hard for the lecturer to work well in the two roles. The scarcity model [16] reveals too many roles or tasks in a job lead someone to the high possibility of the role conflict because of a lack of energy and time. It's led to focuses on one role and less attention on the others as a consequence. In line with, the divergent rewards model [17] finds that research and teaching activities have a different distinctive reward, then drive the employee to focus more on the activity or role that gives the higher return. It means there is a role or task that will be neglect as a consequence. In the personality model [18], teaching and research are jobs with different characteristics; thus, they require different characters. Researchers need a lot less distraction to focus, and it will help to work alone. At the same time, teachers have to communicate and interact with students. It's led to a high possibility of being more distracted.

In sum, it is tough for lecturers to be good in both roles due to high job demands. Consequently, they tend to focus on one role and neglect the other (role conflict). As discussed before, the teacher and researcher role is essential for a lecturer. The roles are unseparated and reciprocal activities to keep pace with the current science development [6]. Hence, if the lecturers only focus on one role and less on the other, it will negatively affect teaching performance (teaching innovation).

Based on previous studies and the literature, we assume that TRC is negatively related to innovative teaching. The dual role that lecturers must carry out leads to the excessive workload because they focus not only on teaching but also on research activity. Conducting the dual roles drains the time and energy of lecturers, consequently lack time to think and make some creativity for the teaching activity. So, if the lecturer loses space and time to think, he/she will be less innovative. Supporting this assumption, previous studies revealed that the role conflict is negatively related to employee innovative work behaviors [19-21]. Further, the increased workload will decrease the innovation potential of employees [22].

Furthermore, according to the JDR model [9], the high job demands drain the energy and strain that caused stress to the employee. Then it has a negative impact on occupational wellbeing. Previous studies show that job demands are highly related to well-being [23-27]. The high job demands will also trigger job stress if the workers need to set great effort to meet the expectations [2]. These studies are supporting our assumption related to the link of TRC to innovative teaching and occupational well-being. 


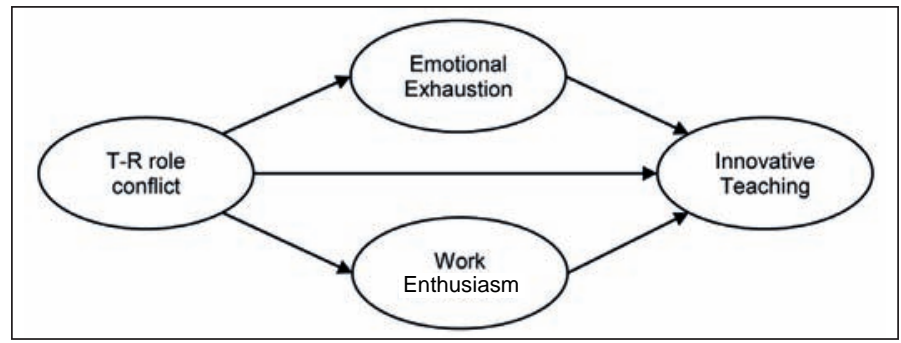

Fig. 1. Research model

\section{Occupational well-being as the mediator}

The occupational well-being of teachers refers to the optimum condition of psychological and work experience [28]. It is indicated from job satisfaction and work enthusiasm and the absence of stress and emotional exhaustion in the teaching activity [29-31]. We concentrate on emotional exhaustion and work enthusiasm to accommodate the positive and negative dimensions of occupational well-being.

Emotional exhaustion points toward burnout's stress dimension, including the feeling of strain, chronic fatigue, and the decrease of emotional resources [32-33]. Moreover, emotional exhaustion prevents the employees from innovative behaviors [2], and impedes the teachers in making a challenging and new learning condition [34]. It may hold the teachers from creating innovative instruction that requires the capacity to prepare complex thoughts.

We first assume that emotional exhaustion plays a mediating variable between TRC and innovative teaching. Supporting this assumption, previous studies found that emotional exhaustion of employees mediated the effect of job demands (time pressure, discipline problems, and role conflict) to the job performance [35]. As we discussed before, TRC results from job demands [2]. The high job demands will drain time and energy, raise the strain, and increase emotional exhaustion. In the end, it will refrain the teacher from creating teaching innovation.

Furthermore, work enthusiasm is related to excitement, enjoyment, and pleasure regarding teaching activity as a teacher [36]. These positive being the teacher's fundamental elements in creating quality instruction [34]. Hence, high work enthusiasm leads teachers to more engagement and good performance, including innovative teaching.

So, we also assume that work enthusiasm mediates the relationship of TRC to innovative teaching. Our assumption was deducting from the previous studies. The previous studies showed that job demands reduced work enthusiasm [29-34], and work enthusiasm also been noted to increase teacher work performance [37]. It has also been found that work engagement, which indicates work enthusiasm, mediates the link between job demands and job outcomes [38].

Based on the literature and previous studies as discussed, we hypothesize as follows:

H1. TRC negatively influence innovative teaching.

H2. Emotional exhaustion mediates the relationship between TRC and innovative teaching.

$\mathrm{H} 3$. Work enthusiasm mediates the relationship between TRC and innovative teaching.

\section{Sample}

\section{Methods}

The survey was conducted randomly on 250 lecturers from nineteen universities in major cities in Indonesia. Among the selected sample, we dropped 17 because it does not meet the sample requirements, conducting teaching and research activities for at least the last three years.

\section{Instruments}

We adapted five items (e.g., "the demands of my teaching interfere with my research", "due to teach-related duties, I have to make changes to my plans for research activities") from the work-family conflict scale [39] to measure the 
Respondents' Characteristic $(\mathrm{N}=233)$

\begin{tabular}{|l|c|c|c|}
\hline & & $\sum$ & $\%$ \\
\hline \multirow{2}{*}{ Gender } & Male & 131 & $56 \%$ \\
\cline { 2 - 4 } & Female & 102 & $44 \%$ \\
\hline \multirow{2}{*}{ Educational Background } & Master & 193 & $83 \%$ \\
\cline { 2 - 4 } & Doctor & 40 & $17 \%$ \\
\hline
\end{tabular}

Table 2

Mean, Standard Deviations and Correlation Among Variables $(\mathrm{N}=233)$

\begin{tabular}{|c|c|c|c|c|c|c|c|}
\hline & Items & Mean & Std. Dev & TRC & EE & WE & IT \\
\hline TRC & 5 & 4.81 & 1.35 & - & & & \\
\hline EE & 4 & 4.67 & 1.24 & $.427^{* * *}$ & - & & \\
\hline WE & 6 & 4.62 & 0.41 & $-.164^{* *}$ & -.112 & - & \\
\hline IT & 6 & 4.62 & 1.16 & $-.512^{* * *}$ & $-.550^{* *}$ & $.161^{*}$ & - \\
\hline
\end{tabular}

Note: $* \mathrm{p}<0.05 ; * * \mathrm{p}<0.01$;RC $=$ teacher-researcher role conflict, $\mathrm{EE}=$ emotional exhaustion, WE $=$ work enthusiasm, IT $=$ innovative teaching

TRC. We also adopted four items (e.g., "I sometimes feel really used up at the end of a school day", "I often notice how listless I am at school") from Maslach Burnout Inventory - Educators Survey (MBI-ES) [40] to measure emotional exhaustion and six items (e.g. "teaching is fun for me", "I really enjoy teaching") from [29] and [36] to measure work enthusiasm. Last, we utilized six items (e.g., "I like to try out new teaching methods", "In my work, I often come up with ideas") of innovative behaviors from [41] to measure innovative teaching.

\section{Data Analysis}

We used structural equation modeling (SEM) in WarpPLS 6.0 to examine the research model. First, we tested the outer model related to the validity and reliability and the inner model related to the goodness of fit. The outer test shows all instruments of the present study are valid (loading factors $>0.7$ ) and reliable (alpha Cronbach $>0.8$ ) [42-44]. Furthermore, the inner model test shows all indicators of research model fit are fit $(\mathrm{APC}<.001 ;$ ARS $<.001$, AVIF $=1.249, \mathrm{GoF}=.381)$ [44].

\section{Result}

Respondents' characteristic in this study ( $\mathrm{Ta}$ ble I) show that the majority were male $(56 \%)$ and female $(44 \%)$. Meanwhile, mostly is a mas- ter's degree $(83 \%)$ and a doctor's degree $(17 \%)$ for the rest.

Table II shows us the mean, deviation, and correlation among the variable of this study. The result shows TRC significantly related to EE, WE, and IT, while EE did not relate to WE.

The analysis was run using WarpPLS to examine all paths in the research model (Fig. 1) simultaneously. The result (Fig. 2) shows us that TRC has a positive effect on $\mathrm{EE}(\beta=.47$, $p<.01)$ and a negative impact on WE $(\beta=-.17$, $p<.01)$. Meanwhile, EE has a negative effect on IT $(\beta=-.38, p<.01)$, and WE has a positive effect on IT ( $\beta=.08, p<.05)$. Furthermore, TRC has a negative effect on IT $(\beta=-.35, p<.01)$ directly. Hence, $\mathrm{H} 1$ received support.

The result of the mediation effect testing (Table III) shows all the paths were significant $(p<.05)$. It indicated occupational well-being (seen from emotional exhaustion and work enthusiasm) is a variable that mediates the relationship between teacher-researcher role conflict and innovative teaching [45]. Moreover, when we are multiplying the path coefficients of both first mediation $[(\mathrm{TRC} \rightarrow \mathrm{EE}) *(\mathrm{EE} \rightarrow \mathrm{IT})$ * $(\mathrm{TRC} \rightarrow \mathrm{IT})]$ and second mediation $[(\mathrm{TRC} \rightarrow \mathrm{WE})$ * $(\mathrm{WE} \rightarrow \mathrm{IT})$ * (TRC $\rightarrow$ IT $)]$, the signs are positive. It indicates the types of mediations are complementary mediation [45]. Thus, both $\mathrm{H} 2$ and $\mathrm{H} 3$ were supported. 


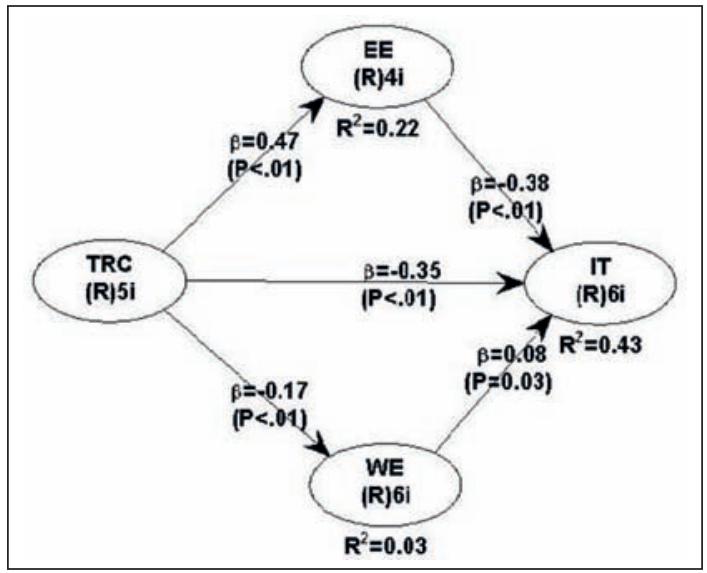

Fig. 2. Relationship between variables

Table 3

The total effect, indirect effects, and direct effect (standardized coeff.)

\begin{tabular}{|l|c|c|c|}
\hline \multirow{2}{*}{ TRC } & \multicolumn{3}{c|}{ IT } \\
\cline { 2 - 4 } & $\beta$ & SE & P values \\
\hline Total effect & -0.5422 & 0.06 & .000 \\
\hline Total indirect effects & -0.1922 & 0.003 & .000 \\
\hline Specific indirect effects & & & .000 \\
\hline through EE & -0.1786 & 0.003 & .004 \\
\hline through WE & -0.0136 & 0.003 & .000 \\
\hline Direct Effect & -0.35 & 0.06 & \\
\hline
\end{tabular}

\section{Discussion}

The result (Fig. 2) shows us that the teacherresearcher role conflict positively affects emotional exhaustion and a negative effect on work enthusiasm. As predicted in the theoretical framework, TRC will raise emotional exhaustion and reduce lecturers' work enthusiasm. The lecturer's great effort to fulfill the job demands (teaching and research) will drain time and energy and be a trigger for job stress. In turn, it is affecting innovative teaching.

These findings support the JDR model, which states job demands are related to the psychological condition [14]. As a teacher and researcher, the dual roles make a lecturer focus on teaching and research activity simultaneously. The dual roles lead to excessive workload, drain time, and energy. Consequently, they lack time and space to think and make some creative for the teaching activity. Thus, they will be less innovative in teaching. This is in line with the findings of previ- ous studies. Role conflict has a negative effect on employees' innovative behavior [19-22].

The present finding is also in line with the previous literature, such as the scarcity model [16], the personality model [18], and the divergent reward model [17]. A lecturer's demands to conduct dual roles simultaneously lead to a high workload and drain time and energy. As a consequence, they will more easily get role conflict (scarcity model). Besides, each job has a unique character that requires a unique personality according to the personality model. Teaching and research also have different characteristics. Thus, it's hard for the lecturer to be good in two different roles.

Moreover, teaching and research activities also provide different reward schemes. These will lead the lecturer to choose and focus on the role, which is more appropriate with his/her personality, gives more rewards, and makes be less attentive to the other roles. In other words, 
the role conflict will cause the lecturer to give high priorities to one of the conflicting job roles and neglect the other role. He/she may feel unwilling to teach when felt teaching activities take a lot of time, reduce research performance, and vice versa.

\section{Mediation effect of occupational well-being}

The result shows that occupational well-being, seen from emotional exhaustion and work enthusiasm, significantly plays as a mediating variable of the relationship between TRC and innovative teaching. According to the positive sign of mediation path coefficient multiplying results, the mediations are partial complementary mediations. It means the mediating variable clarifies, possibly confounds, or falsifies the link between two, antecedent and consequent variables [45-46].

According to the theoretical framework built, emotional exhaustion and work enthusiasm can serve as explanatory variables to explain how TRC is affecting innovative teaching. First, TRC influences innovative teaching through emotional exhaustion. TRC is a consequence of job demands. According to the JDR model, job demands are positively related to emotional exhaustion. Hence, the high role conflict experienced by the lecturer will increase his/her emotional exhaustion. In turn, the high emotional exhaustion will prevent the lecturer from creating a new teaching strategy or method. The high emotional exhaustion also makes the lecturer refrain from creating an attractive learning environment and vice versa. This is consistent with the previous finding. The emotional exhaustion prevents the employee from innovative behavior [2].

Second, TRC influences innovative teaching through work enthusiasm. Based on the JDR model, the rise of TRC will decrease the work enthusiasm of the lecturer. The low work enthusiasm indicates the low of enjoyment, excitement, and pleasure. So, if the lecturer no longer feels joy and pleasure with the job, it will decrease the job performance, including innovative teaching, and vice versa. As revealed in the previous finding, the teacher's enthusiasm manifested the readiness to build up the skills and expertise, dedication to the job, and ultimately led to good performance [37]. The present finding is also consistent with the previous finding that work enthusiasm plays a mediating role in the relationship between job demands and job outcomes [38].

\section{Practical implication}

As we know, innovation is a core of competitive advantage that is essential to remain competitive and survive in the competitive environment [47-48]. Consequently, the university and related institutions should be more concerned about the innovative behavior of the lecturers. This study provides an important insight into the related stakeholders, such as the universities and related ministry, regarding the negative predictor of innovative teaching. They should discover approaches to reduce the negative effect of TRC on the innovation behavior of lecturer's teaching activity. The universities have to ease the issue regarding job role conflict.

There are several points regarding how to mitigate the negative effect. As revealed in this study, the job role conflict is related to the workload, the lecturer's personality, and the roles' reward scheme. First, the administrators may redesign the job structure to reduce the teaching hours and hire guest lecturers to fill the workload gap. Second, the lecturers may be allowed to work at their preferences and personality. For instance, the lecturers who like to teach are permitted to increase their teaching hours, and for lecturers who like to research, the teaching hours may be reduced. Our suggestions are based on the previous finding that the lecturers try to balance the research and teaching activity based on their preferences [7].

Last, the universities may redesign and evaluate the system to balance teaching and research rewards related to the reward scheme. It is necessary to promote the balance of lecturer's motivation on teaching and research. In the Indonesian context, most universities give high rewards to lecturers who can conduct research 
and publications in reputable journals. Consequently, many lecturers choose to conduct research, neglect their teaching activity. This ultimately will decrease the teaching quality.

Hopefully, redesigning the job structure will reduce the workload, especially related to the number of teaching hours. Evaluating the reward system is expected to minimize the job role conflict of lecturers. The low job role conflict will lead to decreasing in emotional exhaustion and promote work enthusiasm. Thus, the innovative teaching of the lecturer will increase as a result.

\section{Conclusion}

This study found that teacher-researcher role conflict (TRC) was significantly related to innovative teaching. The high TRC will reduce the lecturer's innovative behavior on teaching activity, and vice versa. Furthermore, the present finding also reveals that occupational wellbeing (emotional exhaustion and work enthusiasm) acts as a complementary mediating variable to explain the relationship between TRC and innovative teaching. Finally, the university and related institutions should be more concerned about creating a balanced environment for lecturers regarding the job structure and reward system. Hence, the balanced job structure and reward system will encourage lecturers to balanced the dual roles as teachers and researchers.

\section{References}

1. Klaeijsen, A., Vermeulen, M., Martens, R. (2018). Teachers' Innovative Behaviour: The Importance of Basic Psychological Need Satisfaction, Intrinsic Motivation, and Occupational Self-efficacy. Scandinavian Journal of Educational Research. Vol. 62, no. 5, pp. 769-782, doi: https://doi.org/1 0.1080/00313831.2017.1306803

2. Cao, C., Shang, L., Meng, Q. (2020). Applying the Job Demands-Resources Model to Exploring Predictors of Innovative Teaching among University Teachers. Teaching and Teacher Education. No. 89, pp. 103009, doi: https://doi. org/10.1016/j.tate.2019.103009

3. Simplicio, J.S. (2000). Teaching Classroom Educators How to Be More Effective and Creative Teachers. Education. Vol. 120, no. 4, pp. 675-680.
4. Jaskyte, K., Taylor, H., Smariga, R. (2009). Student and Faculty Perceptions of Innovative Teaching. Creativity Research Journal. Vol. 21, no. 1, pp. 111-116, doi: https://doi. org/10.1080/10400410802633673

5. Yin, H., Han, J., Lu, G. (2017). Chinese Tertiary Teachers' Goal Orientations for Teaching and Teaching Approaches: The Mediation of Teacher Engagement. Teaching in Higher Education. Vol. 22, no. 7, pp. 766-784, doi: https://doi.org/ 10.1080/13562517.2017.1301905

6. Jencks, C., Riesman, D. (1968). The Academic Revolution (Vol. 68). New York: Doubleday.

7. Xu, L. (2017). Teacher-Researcher Role Conflict and Burnout among Chinese University Teachers: A Job Demand-Resources Model Perspective. Studies in Higher Education. Vol. 44, no. 6, pp. 903-919, doi: http://dx.doi.org/10.1080/0307 5079.2017.1399261

8. Ababneh, K.I., Hackett, R.D. (2019). The Direct and Indirect Impacts of Job Characteristics on Faculty Organizational Citizenship Behavior in the United Arab Emirates (UAE). Higher Education. Vol. 77, no. 1, pp. 19-36, doi: https://doi. org/10.1007/S10734-018-0252-3

9. Demerouti, E., Bakker, A.B., Nachreiner, F., Schaufeli, W.B. (2001). The Job Demands-Resources Model of Burnout. Journal of Applied Psychology. Vol. 86, no. 3, pp. 499-512, doi: https://psycnet.apa.org/doi/10.1037/00219010.86.3.499

10. Schaufeli, W.B., Taris, T.W. (2014). A Critical Review of the Job Demands-Resources Model: Implications for Improving Work and Health. In: Bauer, G.F., Hämmig, O. (Eds.). Bridging Occupational, Organizational and Public Health: A Transdisciplinary Approach. Dordrecht: Springer Netherlands, pp. 43-68.

11. Mudrak, J., Zabrodska, K., Kveton, P., Jelinek, M., Blatny, M., Solcova, I., Machovcova, K. (2018). Occupational Well-being Among University Faculty: A Job Demands-Resources Model. Research in Higher Education. Vol. 59, no. 3, pp. 325-348, doi: https://link.springer.com/article/10.1007/s11162-017-9467-x

12. Torp, S., Lysfjord, L., Midje, H.H. (2018). Workaholism and Work-Family Conflict among University Academics. Higher Education. Vol. 76, no. 6, pp. 1071-1090, doi: https://doi.org/10.1007/ S10734-018-0247-0

13. Dicke, T., Stebner, F., Linninger, C., Kunter, M., Leutner, D. (2018). A Longitudinal Study 
of Teachers' Occupational Well-Being: Applying the Job Demands-Resources Model. Journal of Occupational Health Psychology. Vol. 23, no. 2, pp. 262-277, doi: https://doi.apa.org/ doi/10.1037/ocp0000070

14. Bakker, A.B., Demerouti, E. (2007). The Job Demands-Resources Model:State of the Art.Journal of Managerial Psychology. Vol.22, no. 3, pp. 309-328, doi: https://doi.org/10.1108/02683940710733115

15. Kingman, J. (1993). The Pursuit of Truth. The Times Higher Education Supplement, June 18.

16. Moore, W. (1963). Man, Time, and Society. New York : Wiley.

17. Ladd, E.C. (1979). The Work Experiences of American College Professors: Some Data and an Argument. Current Issues in Higher Education. Washington, D.C. : American Association of Higher Education.

18. Eble, K. (1976). The Craft of Teaching. New York: Jossey-Bass.

19. Chen, Y., Jiang, Y.J., Tang, G., Cooke, F.L. (2018). High-Commitment Work Systems and Middle Managers' Innovative Behavior in the Chinese Context: The Moderating Role of Work-Life Conflicts and Work Climate. Human Resource Management. Vol. 57, no. 5, pp. 1317-1334, doi: https://doi.org/10.1002/hrm.21922

20. Choi, S.B., Cundiff, N., Kim, K., Akhatib, S.N. (2017). The Effect of Work-Family Conflict and Job Insecurity on Innovative Behaviour of Korean Workers: The Mediating Role of Organisational Commitment and Job Satisfaction. International Journal of Innovation Management. Vol. 22, no. 01, 1850003, doi: https://doi.org/10.1142/ S1363919618500032

21. Ezeh, L.N., Chukwuemeka, E.E., Stephen, E.I., Nnaebue, C.I., Rachael, A.O. (2020). Association of Innovative Work Behaviour, Organizational Frustration and Work-family Conflict among Private Sector Employees. Asian Journal of Advanced Research and Reports. Vol. 8, no. 2, pp. 20-29, doi: https://doi.org/10.9734/ajarr/2020/ v8i230195

22. Kellogg, K. (2002). When Less Is More: Exploring the Relationship Between Employee Workload and Innovation Potential. CGO Insights, 1-4.

23. van den Tooren, M., de Jong, J. (2014). Job Demands-Resources and Employee Health and Well-Being: The Moderating Role of Contract Type. Career Development International. Vol. 19, no. 1, pp. 101-122, doi: http://dx.doi. org/10.1108/CDI-05-2013-0058
24. Bakker, A.B., Demerouti, E., Euwema, M.C. (2005). Job Resources Buffer the Impact of Job Demands on Burnout. Journal of Occupational Health Psychology. Vol. 10, no. 2, pp. 170-180, doi: https://psycnet.apa.org/doi/10.1037/10768998.10.2.170

25. Hakanen, J.J., Bakker, A.B., Schaufeli, W.B. (2006). Burnout and Work Engagement among Teachers. Journal of School Psychology. Vol. 43, no. 6, pp. 495-513, doi: 10.1016/j.jsp.2005.11.001

26. Rafsanjani, M.A., Pamungkas, H., Rahmawati, E.D. (2019). Does Teacher-Student Relationship Mediate the Relation between Student Misbehavior and Teacher Psychological Well-Being? JABE: Journal of Accounting and Business Education. Vol. 4, no. 1, pp. 34-44, doi: http://dx.doi. org/10.26675/jabe.v4i1.8411

27. Rafsanjani, M.A., Ghofur, M.A., Fitrayati, D., Dewi, R.M. (2020). Does Perceived Organizational Support Mitigate the Negative Effect of Teacher- Researcher Role Conflict among Lecturers? (Evidence from Indonesia). Pedagogika. Vol. 138, no. 2, pp. 25-36, doi: https://doi. org $/ 10.15823 /$ p.2020.138.2

28. Ryan, R.M., Deci, E.L. (2001). On Happiness and Human Potentials: A Review of Research on Hedonic and Eudaimonic Well-Being. Annual Review of Psychology. Vol. 52, no. 1, pp. 141166, doi: http://dx.doi.org/10.1146/annurev. psych.52.1.141

29. Aldrup, K., Klusmann, U., Lüdtke, O., Göllner, R., Trautwein, U. (2018). Student Misbehavior and Teacher Well-Being: Testing the Mediating Role of the Teacher-Student Relationship. Learning and Instruction. No. 58, pp. 126-136, doi: https://psycnet.apa.org/doi/10.1016/j.learninstruc.2018.05.006

30. Rafsanjani, M.A., Rahmawati, E.D. (2019). Stress Exposure and Psychological Well-Being: Study on Beginning Teacher. JABE: Journal of Accounting and Business Education. Vol. 3, no. 2, pp. 162-169, doi: http://dx.doi.org/10.26675/jabe.v3i2.5757

31. Diener, E., Suh, E., Lucas, R.E., Smith, H. (1999). Subjective Well-Being: Three Decades of Progress. Psychological Bulletin. Vol. 125, no. 2, pp. 276-302. Available at: https://media.rickhanson. net/Papers/SubjectiveWell-BeingDiener.pdf (accessed 10.04.2021).

32. Maslach, C., Schaufeli, W.B., Leiter, M.P. (2001). Job Burnout. Annual Review of Psychology. Vol. 52, no. 1, pp. 397-422, doi: https://doi. org/10.1146/annurev.psych.52.1.397 
33. Skaalvik, E.M., Skaalvik, S. (2017). Motivated for Teaching? Associations with School Goal Structure, Teacher Self-Efficacy, Job Satisfaction and Emotional Exhaustion. Teaching and Teacher Education. No. 67, pp. 152-160, doi: http:// dx.doi.org/10.1016/j.tate.2017.06.006

34. Aldrup, K., Klusmann, U., Lüdtke, O. (2017). Does Basic Need Satisfaction Mediate the Link between Stress Exposure and Well-Being A Diary Study among Beginning Teacher. Learning and Instruction. No. 50, pp. 21-30, doi: https:// doi.org/10.1016/j.learninstruc.2016.11.005

35. Karatepe, O.M., Beirami, E., Bouzari, M., Safavi, H.P. (2014). Does Work Engagement Mediate the Effects of Challenge Stressors on Job Outcomes? Evidence from the Hotel Industry. International Journal of Hospitality Management. No. 36, pp. 14-22, doi: http://dx.doi.org/10.1016/j. ijhm.2013.08.003

36. Kunter, M., Tsai, Y.-M., Klusmann, U., Brunner, M., Krauss, S., Baumert, J. (2008). Students' and Mathematics Teachers' Perceptions of Teacher Enthusiasm and Instruction. Learning and Instruction. Vol. 18, no. 5, pp. 468-482, doi: 10.1016/j.learninstruc.2008.06.008

37. Wenström, S., Uusiautti, S., Määttä, K. (2018). "The Force that Keeps you Going": Enthusiasm in Vocational Education and Training (VET) Teachers' Work. International Journal for Research in Vocational Education and Training. Vol. 54, no. 4, pp. 244-263, doi: https://doi. org/10.13152/IJRVET.5.4.1

38. Borst, R.T., Kruyen, P.M., Lako, C.J. (2017). Exploring the Job Demands-Resources Model of Work Engagement in Government: Bringing in a Psychological Perspective. Review of Public Personnel Administration. Vol. 39, no. 3, pp. 372-397, doi: https://doi. org/ $10.1177 \% 2$ F0734371X17729870

39. Netemeyer, R.G., Boles, J.S., McMurrian, R. (1996). Development and Validation of WorkFamily Conflict and Family-Work Conflict Scales. Journal of Applied Psychology. Vol. 81, no. 4, pp. 400-410, doi: https://psycnet.apa.org/ doi/10.1037/0021-9010.81.4.400

40. Maslach, C., Jackson, S.E., Leiter, M.P. (1997). Maslach Burnout Inventory: Third Edition. In: Zalaquett, C.P., Wood, R.J. (Eds.). Evaluating
Stress: A Book of Resources. Lanham, MD, US : Scarecrow Education, pp. 191-218.

41. de Jong, J.P.J., Kemp, R. (2003). Determinants of Co-Workers' Innovative Behaviour: An Investigation into Knowledge Intensive Services. International Journal of Innovation Management. Vol. 07, no. 02, pp. 189-212, doi: https:// doi.org/10.1142/S1363919603000787

42. Hair, J.F., Black, W.C., Babin, B.J., Anderson, R.E. (2010). Multivariate Data Analysis, $7^{\text {th }}$ edition. Pearson Prentice Hall.

43. Maholtra, N.K. (1996). Marketing Research. London: Prentice-Hall International, Inc.

44. Solimun, F., Nurjannah. (2017). Metode Statistika Multivariat Pemodelan Persamaan Struktural (SEM) Pendekatan WarpPLS. Malang: Universitas Brawijaya Press.

45. Zhao, X., Lynch, J. G., Jr., Chen, Q. (2010). Reconsidering Baron and Kenny: Myths and Truths about Mediation Analysis. Journal of Consumer Research. Vol. 37, no. 2, pp. 197-206, doi: https:// doi.org/10.1086/651257

46. Nitzl, C., Roldan J.L., Cepeda, G. (2016). Mediation Analysis in Partial Least Squares Path Modeling: Helping Researchers Discuss More Sophisticated Models. Industrial Management \& Data Systems. Vol. 116, no. 9, pp. 1849-1864, doi: https://doi.org/10.1108/IMDS-07-2015-0302

47. Koch, A.K., Adler, M. (2018). Emotional Exhaustion and Innovation in the Workplace - A Longitudinal Study. Industrial Health. Vol. 56, no. 6, pp. 524-538, doi: https://dx.doi.org/10.2486\%2F indhealth.2017-0095

48. Huhtala, H., Parzefall, M.-R. (2007). A Review of Employee Well-Being and Innovativeness: An Opportunity for a Mutual Benefit. Creativity and Innovation Management. Vol. 16, no. 3, pp. 299-306, doi: https://doi.org/10.1111/j.14678691.2007.00442.x

Acknowledgments. Universitas Negeri Surabaya supported this research. The authors also thank Purba Andy Wijaya (Universitas Islam Riau) who provided expertise to the research.

The paper was submitted 12.12.20 Accepted for publication 07.04.21 